\title{
Strategies to Improve the Effectiveness of Classroom Teaching of Morality and Rule of Law in Primary Schools
}

\author{
Shiyun Guo \\ Xiang'an No. 1 Primary School affiliated to Fujian Institute of Education, Xiamen 361100, Fujian, China \\ Email: 495384306@qq.com
}

\begin{abstract}
Students in primary school are in the critical stage of physical and mental growth, school education should be conducted not only in the students' learning situation, the cultivation and learning in morality and legal concept for students should also be given top priority so as to create teaching environment and design based teaching content for students in developing correct values and outlook on life. The discipline of morality and rule of law in primary schools focuses on cultivating students' moral accomplishment and concept of rule of law, so that students can have a comprehensive concept of morality and rule of law from the perspective of themselves, family, collectivism and then the society on the whole, thus forming independent thinking ability and attitude of with comprehensive quality. The physical and mental healthy growth of students in primary school is an indispensable part of teaching activities in primary school. This paper will also put forward some corresponding teaching practices to provide reference for improving the effectiveness of classroom teaching in morality and rule of law in primary school.
\end{abstract}

Keywords: students in primary school, morality and the rule of law, classroom teaching strategy, effective measures

\section{Introduction}

From the first grade of primary school, the first discipline for students is on morality and rule of law, which is the beginning of the school to cultivate and guide students to establish correct life values. Primary school students have a certain self-knowledge of external things, so plasticity is a prominent feature of all students, students temporarily haven't developed independent and complete ideology, as a result, it is of paramount importance in what kind of education on ideology and rule of law students receive, which matters in whether students can develop good personal accomplishment and positive attitude towards life. The discipline in morality and rule of law in of primary school is the result of continuous innovation and improvement of teaching standards and teaching concepts in the process of teaching reform in the new era, which truly reflects the great reform of school education with students as the teaching focus and students' growth trajectory as the teaching goal. School based education should give top priority on imparting knowledge and enabling students to establish a healthy body and a correct value of life with all-round development, so that students can develop habits with good behavior and legal cognition in moral and legal teaching.

\section{Measures to improve the effectiveness of classroom teaching of ethics and rule of law in primary schools}

\subsection{Create contextualized teaching to arouse students' emotional resonance}

Situational teaching is generally divided into two kinds: life based situational teaching and simulation based situational teaching. First, the topic is on the effectiveness of life based situational teaching. Classroom learning of morality and rule of law is inseparable from students' real life, and it is the main way to integrate students' familiar life into classroom teaching in morality and rule of law class in situational teaching. On morality and the rule of law textbook content, the teachers introduce daily life of students in classroom teaching to create of the life based situational teaching model, as a result, the students will become lecturers in the classroom teaching with teachers just as auxiliaries and guiders who take the charge in sorting and integrate knowledge so as to fully mobilize the enthusiasm of students' autonomous learning. Therefore, the classroom will become the major front for independent thinking.

Secondly, the topic is on the effectiveness of simulated situational teaching. In teaching of discipline of morality and the rule of law, teachers plan the teaching content in advance according to the content of the textbook, and set up the corresponding teaching situation centering on the content of the textbook to attract students' attention and arouse curiosity. Context can create a vivid learning environment for students, help students experience the artistic conception expressed by 
the content of textbooks to enable students to understand knowledge in legality and rule of law in a more intuitive and threedimensional manner. Contextualized teaching can shorten the distance between students and teachers, making students more convinced of the moral and legal theory taught by teachers, and arouse students' emotional resonance. Students can not only learn new knowledge, but also apply it in their study and life to improve their moral and theoretical literacy.

For example, in the first volume textbook for grade four of primary school, teachers can ask students to discuss the topic in groups in the unit learning of My Contribution to Family and Responsibility, and students are encouraged to simulate the situation of family life. Finally, what are the contributions and responsibilities of parents and their own families?After students make the statements in turn, teachers will give positive analysis and evaluation in time. Every student has their own ideas about their parents' contributions. Students are required tell their own contributors and family responsibilities through their own observations. In order to promote independent thinking and active statement of students, teachers can also give students an example of their own family contribution and responsibility, so that students have a deeper understanding of contribution and responsibility. Finally, after discussion of the family contribution and responsibility, the teacher can also sublimate the theme to the individual contribution and responsibility to the society, the contribution and responsibility to the country, to sow a small seed to love the motherland and the people in every student's heart.

\subsection{Adhere to the original intention of student-oriented teaching, integrate and optimize teaching content}

Primary education should give the focus on both teaching cultural knowledge for students and students' mental health growth. In the new era of primary education and teaching environment, the society, parents and schools attach great importance to the teaching of morality and rule of law in primary schools. How to improve the effectiveness of the classroom teaching of morality and rule of law has become the focus of teachers. First of all, teaching must be conducted in the spirit of students as the original aspiration, and all effective resources can be utilized to integrate and optimize the teaching content of morality and rule of law, so as to make the classroom teaching content more wonderful and attractive. On the premise of student-oriented, the integration and optimization of teaching content can mainly be made based on the followings: First, as the guider and assistant in morality and rule of law based classroom teaching, teachers should constantly absorb new teaching reform theories and make innovation in new teaching forms and make exploration for vitality in classroom teaching on the basis of textbook content. Primary school students are not mature mentally, and their personality characteristics and interests are different. Teachers should create teaching methods and forms according to the growth characteristics of students in order to promote students to love the discipline of morality and rule of law under the personalized and diversified character development environment, as a result, students will show their passion for this discipline from the bottom of their heart, rather than in a passive manner. Therefore, students will have a in-depth awareness that morality and rule of law are used in our daily life, which can be used for all the students in a visible manner. Second, the rational use of Internet multimedia classroom teaching.

Under the impact of high technology, podium is not the only position for classroom teaching, the use of Internet multimedia based teaching has become an effective auxiliary teaching means of primary school teaching. In the classroom teaching of morality and rule of law in primary schools, teachers should encourage students to watch corresponding videos according to the content of textbooks, and transform abstract theoretical knowledge into visible and specific images, which are easier for students to accept and understand. Teachers can also show the knowledge of the textbooks to students in the form of pictures or PPT, so that students can discuss and speak after watching, so as to maximize the participation and enthusiasm of students, so that students can think spontaneously and speak actively, and effectively promote the effectiveness of classroom teaching.

\subsection{Change the teaching concept and attach importance to the teaching of ethics and rule of law}

According to the student-centered teaching concept of the new curriculum reform standard, more attention should be paid to the overall development of students, especially to the cultivation of students' comprehensive quality, which is an important concept that needs to be changed in the school teaching reform and family education. In the traditional teaching mode, students' academic performance is the most important, which is also the top concern of school and family. Our country has completely denied this traditional and obsolete thought in the education reform. The new idea of education and teaching takes students as the main body, which aims to establish and improve quality education for the development of students' individual and diversified character. The initial goal of educational reform and development is to enable every student grow up healthily and freely in a happy and relaxed atmosphere for happy and independent learning. Therefore, the traditional thinking should be transformed in school education and family education. The school should change its teaching concept, pay full attention to the subject of morality and the rule of law, recognize the importance of moral and legal teaching courses 
from the teaching concept, and give teachers their due teaching status and teaching tools.

Family education should be give focus on morality and the rule of law. The content of this subject is basically guided and influenced by morality and the rule of law centering on the growth characteristics and growth track of students, so that students can develop the quality of morality and the rule of law at an early age, and acquire knowledge, so as to shape a good principle of conduct for students' words and deeds. Students should also attach importance to the study of morality and rule of law in the study of Chinese and mathematics, and think about the problems raised by teachers in class in a meticulous manner, study and discuss the knowledge system of morality and the rule of law and transform forced learning into active learning so as to increase their knowledge reserve and establish a complete knowledge system, which not only broaden their horizons in learning, and an independent personality can be fostered. In addition, students should master book knowledge when studying the discipline of morality and the rule of law. What is more important is that students practice and use it in their personal behavior, daily study and daily life, which is the significance of the course system of morality and rule of law. Students not only learn relevant theoretical knowledge, but also practice it in life, which is existence significance of improving the effectiveness and the theoretical knowledge of morality and rule of law.

\section{The practical significance of improving the effectiveness of classroom teaching of ethics and rule of law in primary schools}

\subsection{Conducive to cultivating primary school students to develop good moral and legal literacy}

With the continuous reform and promotion of the new curriculum standard, school education is no longer conducted with focus on grade as the top priority in the traditional teaching. The school education concept has undergone substantial changes, which are mainly reflected in the teaching plan and teaching content planning from the perspective of students' growth. The classroom in primary school is no longer conducted with disciplines of Chinese, mathematics and English as the most important courses in teaching activities, rather, physical education, music, art and morality and rule of law are give equal importance in daily teaching. Such scientific subject classification is not only the result of education and teaching reform, but also an important reference element of school education and teaching plan. Stage of primary school is an important stage for students to accept conventional, systematic and scientific knowledge, but also an important period for students to form correct moral concepts and legal concepts. The effective teaching of morality and rule of law course can help students develop the concept of morality and rule of law, and lay a good foundation for students' correct outlook on life, values and world outlook. In daily teaching process, teachers in the classroom teaching content, teaching methods and teaching interaction, want to combine the students' personality characteristics, growth characteristics and interests, avoid by all means make any teaching strategy can not from student's life, to adhere to the moral and the rule of law of the abstract knowledge comb into image, visual, specific life scene, Let students personally feel morality and rule of law is the matter and people around.

\subsection{Conducive to enriching campus life and broadening students' horizons}

At primary school stage, students begin to study morality and the rule of law in the first grade, From the perspective of teaching content and teaching objectives, the study of morality and rule of law is aimed at cultivating students to integrate morality and rule of law into their original ideas, so that students can change their thoughts from preschool to primary school, and help students realize what they should "do and how to do. "The lower grades study ethics and the rule of law, and textbooks are often filled with interesting illustrations, supplemented by text, so that students can learn the knowledge of morality and rule of law more intuitively. The theme of each unit of the textbook is closely related to the growth of students, and provides the corresponding ideological and moral and basic principles of human conduct, and sets a benchmark and example for students to develop good behavior and character.

At primary school stage, Students are still in the growing stage of mind, and their understanding of morality and the rule of law needs to be further improved. Their cognitive ability and judgment ability to treat things are limited, and their morality and the rule of law need to be further improved and strengthened, which to a large extent shows the importance of the discipline of morality and the rule of law. In the classroom teaching of morality and the rule of law, teachers can carry out interactive teaching, multi-level teaching and life situational teaching according to the teaching content. They can also use multimedia teaching tools to make students perceive the charm of morality and rule of law from different perspectives, materials and teaching designs. It is a subject that enriches primary school students and broadens their horizons. This subject is usually a long-term, continuous and systematic teaching effect. Only in the teaching process, can students be subtly guided to transform moral and legal knowledge into personal quality of behavior and character, which can be truly reflected in students' words and deeds and conduct style. 


\section{Conclusion}

Teachers should always set up teaching contents and teaching methods from the perspective of students in teaching of morality and rule of law in primary school. By combining diversified teaching concepts and Internet multimedia, students can be encouraged to integrate themselves into the study of morality and rule of law courses to cultivate themselves to develop good personal qualities in morality and rule of law, and then form correct values of life.

\section{References}

[1] Zhu Jun. Strategies to improve the effectiveness of classroom teaching in morality and rule of law[J]. Classroom Teaching, 2021; 11 .

[2] Li Wanpeng. Strategies to improve the effectiveness of classroom teaching in morality and rule of law[J]. Research in Teaching, 2020; 16.

[3] Zhang Zhonghua. Strategies to improve the effectiveness of classroom teaching in morality and rule of law[J]. Education for Chinese After-school, 2020; 5. 